\title{
GAMBARAN TINGKAT PENGETAHUAN MASYARAKAT DI DUSUN SIAGA KELURAHAN SUNGAI RAYA TENTANG OBESITAS SENTRAL
}

\section{OVERVIEW OF COMMUNITY KNOWLEDGE LEVELS IN SIAGA HAMLET, SUNGAI RAYA VILLAGE ABOUT CENTRAL OBESITY}

\author{
Heny Puspasari ${ }^{1}$ ), Weni Puspita ${ }^{2}$, Dian Katikasari $^{3}$, Sinta $^{4}$ \\ ${ }^{(1,2)}$ Akademi Farmasi Yarsi Pontianak \\ ${ }^{(3,4)}$ Jurusan Diploma III Farmasi Akademi Farmasi Yarsi Pontianak \\ Jl. Panglima A'im no 02 Pontianak \\ email:heny24puspasari@gmail.com
}

Submitted : 18 Agustus 2021 Reviewed: 22 September 2021 Accepted : 30 September 2021

\begin{abstract}
ABSTRAK
Obesitas sentral adalah kondisi kelebihan lemak pada bagian perut. Prevalensi obesitas sentral di Indonesia menurut Riset Kesehatan Dasar tahun 2018 pada penduduk umur $\geq 15$ tahun mengalami peningkatan dalam beberapa tahun. Pada tahun 2007 prevalensi obesitas sentral sebesar 18,8\%. Pada tahun 2013 prevalensi obesitas sentral sebesar 26,6\% dan pada tahun 2018 prevalensi obesitas sentral sebesar 31,0\%. Tujuan penelitian ini untuk mengetahui tingkat pengetahuan masyarakat di Dusun Siaga Kelurahan Sungai Raya tentang obesitas sentral pada ibu-ibu rumah tangga. Jenis penelitian yang dilakukan yaitu dengan metode deskriptif dengan pendekatan prospektif. Pengambilan sampel dilakukan menggunakan teknik nonprobability sampling dengan teknik sampling jenuh pada ibu-ibu rumah tangga di Dusun Siaga Desa Sungai Raya RT 10 RW 06 sebanyak 45 orang. Pengukuran yang dilakukan meliputi lingkar pinggang dengan menggunakan pita ukur meteran dan pengetahuan responden dengan menggunakan kuesioner. Hasil penelitian yang diperoleh diolah menggunakan uji analisis statistic deskriptif. Hasil analisis statistic deskriptif mengenai obesitas sentral menunjukkan bahwa lebih banyak responden yang memiliki pengetahuan kurang dengan persentase sebanyak 22 orang (48,9\%), pengetahuan yang cukup sebanyak 17 orang $(37,8 \%)$ dan pengetahuan yang baik sebanyak 6 orang $(13,3 \%)$. Berdasarkan hasil penelitian dapat disimpulkan bahwa tingkat pengetahuan masyarakat Dusun Siaga Kelurahan Sungai Raya tentang obesitas sentral masih kurang.
\end{abstract}

Kata kunci: Gambaran, pengetahuan, obesitas sentral.

\section{ABSTRACT}

Central obesity is a condition of excess fat in the abdomen. The prevalence of central obesity in Indonesia according to the 2018 Basic Health Research in the population aged 15 years has increased in several years. In 2007 the prevalence of central obesity was $18.8 \%$. In 2013 the prevalence of central obesity was $26.6 \%$ and in 2018 the prevalence of central obesity was $31.0 \%$. The purpose of this study was to determine the level of knowledge of the 
community in Dusun Siaga, Sungai Raya Village about central obesity in housewives. The type of research conducted is descriptive correlation method with a prospective approach. Sampling was carried out using a non-probability sampling technique with a saturated sampling technique on housewives in Siaga Hamlet, Sungai Raya Village RT 10 RW 06 as many as 45 people. Measurements taken include waist circumference using a tape measure and respondents' knowledge using a questionnaire. The research results obtained were processed using descriptive statistical analysis tests. The results of descriptive statistical analysis on central obesity show that more respondents have less knowledge with a percentage of 22 people (48.9\%), sufficient knowledge of 17 people (37.8\%) and good knowledge of 6 people $(13.3 \%)$. Based on the results, it is concluded that the level of knowledge of respondents about central obesity is more respondents who have less knowledge about central obesity.

Keywords: Description, knowledge, central obesity.

\author{
Penulis Korespondensi : \\ Heny Puspasari \\ Akademi Farmasi Yarsi Pontianak \\ Jl. Panglima A'im no 02 Pontianak \\ email:heny24puspasari@gmail.com
}

\title{
PENDAHULUAN
}

Obesitas sentral merupakan permasalahan gizi yang ada di masyarakat. Menurut WHO (2014) obesitas sentral adalah kondisi lemak berlebihan yang terpusat pada daerah perut (intra-abdominal fat). Obesitas menjadi salah satu masalah kesehatan masyarakat di negara maju maupun negara berkembang. Prevalensi obesitas sentral pada pria di Amerika sebesar 23,5\% dan pada wanita sebesar 29,7\%. Prevalensi obesitas sentral pada pria di Asia sebesar $1,7 \%$ dan pada wanita sebesar 3,7\%. Prevalensi obesitas sentral di Indonesia menurut Riset Kesehatan Dasar tahun 2018 pada penduduk umur $\geq 15$ tahun mengalami peningkatan dalam beberapa tahun. Pada tahun 2007 prevalensi obesitas sentral sebesar 18,8\%. Pada tahun 2013 prevalensi obesitas sentral sebesar 26,6\% dan pada tahun 2018 prevalensi obesitas sentral sebesar 31,0\% (Kemenkes RI, 2018).Hasil survei nasional tentang obesitas sentral menurut data Riskesdas 2018 di Provinsi Kalimantan Barat menunjukkan angka prevalensi yaitu sebesar $25,59 \%$. Prevalensi obesitas sentral pada penduduk umur $\geq 15$ tahun di Kabupaten Kubu Raya menurut data Riskesdas 2018 adalah 21,06\%. Berdasarkan data prevalensi obesitas sentral di berbagai kota, khususnya di Kalimantan Barat menunjukkan kejadian obesitas sentral di Kabupaten Kubu Raya masuk ke dalam peringkat sepuluh besar kejadian terbanyak obesitas sentral dengan persentase sebesar 21,06\% (Kemenkes RI, 2018).

Pengetahuan merupakan hasil penginderaan manusia, atau hasil tahu seseorang terhadap objek melalui indera yang dimilikinya (mata, hidung, telinga dan sebagainya). Sebagian besar pengetahuan seseorang diperoleh melalui indera pendengaran (telinga) dan indera penglihatan (mata). Pengetahuan gizi meliputi pengetahuan tentang pemilihan dan konsumsi sehari-hari dengan baik dan memberikan semua zat gizi yang dibutuhkan untuk fungsi normal tubuh (Notoatmodjo, 2012).

Berdasarkan uraian latar belakang di atas, dilakukan penelitian dengan tujuan untuk mengetahui gambaran tingkat pengetahuan masyarakat di Dusun Siaga Kelurahan Sungai Raya tentang obesitas sentral.

\section{BAHAN DAN METODE}

Metode yang digunakan dalam penelitan ini adalah metode penelitian survei deskriptif. Penelitian ini menggunakan pendekatan analisis kuantitatif. Pengambilan data secara prosfektif kepada semua ibu-ibu rumah tangga yang berada di Dusun Siaga Desa Sungai Raya RT 10 RW 06. Kriteria inklusi adalah ibu rumah tangga yang berusia 25-65 tahun, sudah menikah, tidak bekerja di luar rumah dan bersedia menjadi responden dengan menandatangani informed consent yang diberikan. Jumlah sampel yang diambil adalah 
seluruh populasi ibu-ibu rumah tangga di Dusun Siaga Desa Sungai Raya RT 10 RW 06 yang berjumlah 45 orang.

Kategori penilaian untuk tingkat pengetahuan yaitu : baik (76-100\%), cukup (56$75 \%)$, kurang $(<55 \%)$. Instrumen yang digunakan adalah kuisioner. Kuisioner ini digunakan untuk mengetahui tingkat pengetahuan masyarakat terhadap kejadian obesitas sentral. Instrumen tersebut dilakukan uji statistic deskriptif. Kuesioner yang telah di berikan kepada 40 responden ibu-ibu rumah tangga dilakukan pengolahan data menggunakan program SPSS dan diperoleh nilai probabilitas [sig.(2-tailed)] kurang dari $(\alpha 0.05)$ dan hasil reliabilitas kuesioner menunjukkan nilai Cronbach's Alpha sebesar 0.895 dapat disimpulkan kuesioner telah valid dan reliabel.

\section{Analisis Data}

Analisis data dalam penelitian ini dilakukan secara statistic deskriptif. Prosedur analisis ini dapat dijelaskan dengan menggunakan rumus Bungin (2010) sebagai berikut :

$$
P={ }_{N}^{F} \times 100 \%
$$

Keterangan : $\mathrm{P}=$ Persentase $(\%)$

$\mathrm{F}=$ Jumlah jawaban yang diperoleh

$\mathrm{N}=$ Jumlah responden

\section{HASIL DAN PEMBAHASAN}

\section{Karakteristik Responden}

\section{a. Usia}

Desa Sungai Raya terletak di wilayah Kecamatan Sungai Raya Kabupaten Kubu Raya, di Kecamatan Sungai Raya terdapat 14 desa dan salah satu diantaranya adalah Desa Sungai Raya. Desa Sungai Raya terbagi menjadi 5 dusun, salah satunya adalah Dusun Siaga. Adapun jumlah penduduk di Dusun Siaga adalah 7.071 jiwa yang terdiri dari 1984 Kepala Keluarga (KK) dengan jumlah RT sebanyak 24 RT dan jumlah RW sebanyak 3 RW (Profil Desa, 2020).

Data yang diperoleh dari Dusun Siaga Desa Sungai Raya Kecamatan Sungai Raya Kabupaten Kubu Raya Tahun 2020 didapatkan jumlah ibu rumah tangga yang hanya berprofesi sebagai ibu rumah tangga saja sebanyak 45 orang. Karakteristik responden berdasarkan kelompok umur di Dusun Siaga Desa Sungai Raya Kecamatan Sungai Raya Kabupaten Kubu Raya dapat dilihat pada tabel di bawah ini : 


\section{Tabel I. Karakteristik Responden Berdasarkan Umur di Wilayah Dusun Siaga Desa Sungai Raya Tahun 2021}

\begin{tabular}{rrrrrr}
\hline & & & $\begin{array}{r}\text { Valid } \\
\text { Percent }\end{array}$ & $\begin{array}{r}\text { Cumulative } \\
\text { Percent }\end{array}$ \\
\hline Valid & $25-30$ & 7 & 15.6 & 15.6 & 15.6 \\
& $31-36$ & 4 & 8.9 & 8.9 & 24.4 \\
& $37-42$ & 4 & 8.9 & 8.9 & 33.3 \\
& $43-48$ & 13 & 28.9 & 28.9 & 62.2 \\
& $49-54$ & 7 & 15.6 & 15.6 & 77.8 \\
& $55-60$ & 6 & 13.3 & 13.3 & 91.1 \\
& $61-66$ & 4 & 8.9 & 8.9 & 100.0 \\
& Total & 45 & 100.0 & 100.0 & \\
\hline
\end{tabular}

Sumber : Data Olahan, 2021

Berdasarkan tabel diatas, menunjukan jumlah responden lebih banyak adalah 43-48 tahun dengan persentase sebanyak 13 responden $(28,9 \%)$. Hal ini sama dengan penelitian lain yang mengatakan bahwa obesitas sentral sangat erat hubungannya dengan umur. Semakin bertambahnya umur maka metabolisme yang terjadi di dalam tubuh mengalami penurunan, lalu akan terjadi perubahan secara biologis yaitu menurunnya fungsi dari otototot. Menurunnya fungsi otot dapat menyebabkan energi yang dikeluarkan tubuh untuk beraktivitas juga semakin sedikit, sehingga lemak di dalam tubuh semakin meningkat (Novitasary, 2013).

\section{b. Pekerjaan}

Berdasarkan karakteristik pekerjaan responden, menunjukan seluruh responden sebanyak 45 orang $(100 \%)$ tidak memiliki pekerjaan (ibu rumah tangga). Hal ini sama dengan penelitian lain yang mengatakan bahwa ibu rumah tangga memegang peranan yang sangat penting dalam suatu rumah tangga. Sehingga kesehatan ibu perlu diperhatikan demi keberlangsungan keluarga. Ibu rumah tangga rentan memiliki gaya hidup tidak sehat. Hal ini diperkuat lagi dengan pekerjaan utama subjek yang semuanya ibu rumah tangga yang hampir melakukan semua aktivitas rumah tangga mulai dari urusan dapur, membersihkan, mencuci dan kegiatan rumah tangga lainnya. Subjek yang diteliti pada umumnya mereka yang melakukan kegiatan di dapur, hal inilah yang memicu tingginya asupan makanan sehingga energi pun meningkat (Mustamin, 2010).

\section{c. Obesitas Sentral}

Data yang diperoleh dari Dusun Siaga Desa Sungai Raya Kecamatan Sungai Raya Kabupaten Kubu Raya Tahun 2020 didapatkan jumlah ibu rumah tangga yang berprofesi sebagai ibu rumah tangga saja sebanyak 45 orang. Karakteristik responden berdasarkan kategori mengalami obesitas sentral dengan pengambilan data dilakukan pengukuran lingkar pinggang di Dusun Siaga Desa Sungai Raya Kecamatan Sungai Raya Kabupaten Kubu Raya dapat dilihat pada tabel di bawah ini : 


\section{Tabel II. Distribusi Frekuensi Responden Berdasarkan Obesitas Sentral di Wilayah Dusun Siaga Desa Sungai Raya Tahun 2021}

Cumulative

Frequency Percent Valid Percent Percent

\begin{tabular}{lccccc}
\hline Valid & $<80 \mathrm{~cm}$ & 4 & 8.9 & 8.9 & 8.9 \\
& $>80 \mathrm{~cm}$ & 41 & 91.1 & 91.1 & 100.0 \\
& & & &
\end{tabular}

Sumber : Data Olahan, 2021

Berdasarkan tabel diatas, menunjukan jumlah responden lebih banyak adalah responden yang mengalami obesitas sentral dengan persentase sebanyak 41 responden $(91,1 \%)$ dan paling sedikit yang tidak obesitas sentral sebanyak 4 responden $(8,9 \%)$. Hal ini sama dengan penelitian lain yang mengatakan bahwa obesitas sentral merupakan penumpukan lemak dalam tubuh pada bagian perut yang diakibatkan jumlah lemak yang berlebih pada jaringan lemak subkutan dan lemak viseral perut. Dari data tersebut dapat diketahui bahwa kejadian obesitas sentral cukup tinggi. Obesitas sentral terjadi jika selama periode tertentu, yaitu dimana energi yang masuk melalui makanan lebih banyak daripada energi yang digunakan untuk menunjang kebutuhan energi tubuh, yang kemudian disimpan menjadi lemak (Listiyana, 2013).

Tabel III. Distribusi Frekuensi Responden Berdasarkan Pengetahuan di Wilayah Dusun Siaga Desa Sungai Raya Tahun 2021

\begin{tabular}{lrrrrr}
\hline & & Frequency & Percent & Valid Percent & $\begin{array}{r}\text { Cumulative } \\
\text { Percent }\end{array}$ \\
\hline Valid & Kurang & 22 & 48.9 & 48.9 & 48.9 \\
& Cukup & 17 & 37.8 & 37.8 & 86.7 \\
& Baik & 6 & 13.3 & 13.3 & 100.0 \\
& & & & \\
& Total & 45 & 100.0 & 100.0 & \\
\hline
\end{tabular}

Sumber : Data Olahan, 2021

Berdasarkan tabel di atas menunjukkan jumlah responden lebih banyak adalah responden yang memiliki pengetahuan kurang mengenai obesitas sentral dengan persentase sebanyak 22 orang $(48,9 \%)$ daripada responden yang memiliki pengetahuan yang cukup dan baik. Hal ini sama dengan penelitian lain yang mengatakan bahwa pengetahuan mempengaruhi terjadinya obesitas, pengetahuan tentang pengaturan makanan, cara pengolahan makanan dan kandungan gizi dalam bahan makanan sangat mempengaruhi asupan makan seseorang dan memberikan risiko yang sangat besar terjadinya obesitas (Tarigan, 2017). Wanita usia subur (WUS) dengan pengetahuan rendah akan beresiko sebesar 0,4 kali mengalami obesitas daripada orang yang memiliki pengetahuan tinggi. 
Kurangnya pengetahuan gizi atau kurangnya kemampuan untuk menerapkan informasi yang diperoleh dalam kehidupan sehari-hari merupakan faktor penting dalam penentuan status gizi seseorang. Resiko terjadinya obesitas dapat dikurangi dengan memahami dan memiliki pengetahuan yang baik mengenai pentingnya hidup sehat, pencegahan terjadinya obesitas dan mengenali tindakan dalam kehidupan sehari hari yang dapat menyebabkan obesitas (Hutasoit, 2020).

\section{KESIMPULAN}

Berdasarkan hasil penelitian yang dilakukan terhadap 45 orang responden mengenai Gambaran Tingkat Pengetahuan Masyarakat di Dusun Siaga Kelurahan Sungai Raya Tentang Obesitas Sentral Tahun 2021 dapat disimpulkan bahwa tingkat pengetahuan responden tentang obesitas sentral lebih banyak responden yang memiliki pengetahuan kurang dengan persentase sebanyak 22 orang $(48,9 \%)$ dari pada responden yang memiliki tingkat pengetahuan cukup sebesar 17 orang (37.8) dan tingkat pengetahuan baik sebanyak 6 orang (13.3\%), sehingga dapat disimpulkan tingkat pengetahuan masyarakat Dusun Siaga Kelurahan Sungai Raya tentang obesitas sentral masih kurang.

\section{UCAPAN TERIMA KASIH}

Ucapan terima kasih peneliti kepada dana penelitian internal Akademi Farmasi Yarsi Pontianak tahun 2021 serta teman-teman anggota penelitian internal.

\section{DAFTAR PUSTAKA}

Bungin, Burhan. (2010). Metodologi Penelitian Kualitatif. PT. Raja Grafindo Persada. Jakarta.

Hutasoit, Eva Santi. (2020). Faktor Yang Mempengaruhi Obesitas Pada Wus di Wilayah Kerja Puskesmas Payung Sekaki Kota Pekanbaru 2019. JOMIS (Journal of Midwifery Science). Volume 4 Nomor 1, Januari Tahun 2020 : 25-33.

Kementerian Kesehatan Republik Indonesia. (2018). Laporan Nasional Riskesdas. Badan Penelitian dan Pengembangan Kesehatan. Jakarta.

Kementerian Kesehatan Republik Indonesia. (2018). Laporan Provinsi Kalimantan Barat Riskesdas. Badan Penelitian dan Pengembangan Kesehatan. Jakarta.

Listiyana, Aulia Dewi, dkk. 2013. Obesitas Sentral dan Kadar Kolesterol Darah Total. Jurnal Kesehatan Masyarakat. (Online), Volume 9, No. 1, (http://journal.unnes.ac.id/nju/index.php/kemas, diakses 23 Januari 2021).

Masturoh, Imas, dkk. (2018). Metodologi Penelitian Kesehatan. Kemenkes RI. Jakarta.

Mustamin. (2010). Asupan Energi dan Aktivitas Fisik Dengan Kejadian Obesitas Sentral Pada Ibu Rumah Tangga di Kelurahan Ujung Pandang Baru Kecamatan Tallo Kota Makassar. Jurnal Media Gizi Pangan. Volume X Nomor 2, Desember Tahun 2010 : 60-65.

Notoatmodjo. (2012). Metodologi Penelitian Kesehatan. Rineka Cipta. Jakarta.

Novitasary, Meiriyani Deliana, dkk. (2013). Hubungan Antara Aktivitas Fisik Dengan

Obesitas Pada Wanita Usia Subur Peserta Jamkesmas di Puskesmas Wawonasa 
Kecamatan Singkil Manado. Jurnal e-Biomedik (eBm). Volume 1 Nomor 2, Juli Tahun 2013 : 1040-1046.

Nursalam. (2017). Metodologi Penelitian Ilmu Keperawatan : Pendekatan Praktis. Salemba Medika. Jakarta.

Sudikno, dkk. (2018). Obesitas Sentral Pada Orang Dewasa : Studi Kohor Prospektif di Kota Bogor. Journal of The Indonesian Nutrition Association. (Online), Volume 41, No. 2, (http://ejournal.persagi.org/index.php/Gizi_Indon, diakses 13 Januari 2021).

Surachman, dkk. (2016). Metodologi Penelitian Kesehatan. Kemenkes RI. Jakarta.

Tarigan, Novriani. (2017). Pengetahuan Gizi Seimbang, Aktivitas Fisik dan Obesitas Sentral Peserta Senam Aerobik di Tama Gym Komplek Riviera Medan. Wahana Inovasi. Volume 6 Nomor 1, Juni Tahun 2017 : 27-34. 
